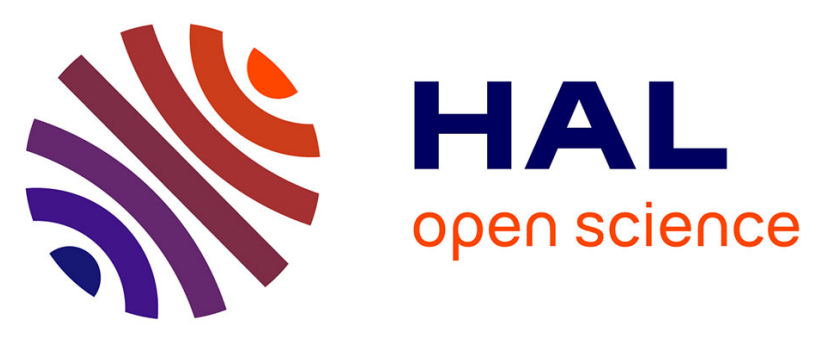

\title{
2-Amino-1-(4-aminophenyl)-1H-pyrrolo(2,3- b)quinoxaline-3- carbonitrile as an efficient inhibitor for the corrosion of C38 steel in hydrochloric acid solution
}

Mounim Lebrini, W. Benkayba, Charafeddine Jama, Fouad Bentiss, Christophe Roos

\section{To cite this version:}

Mounim Lebrini, W. Benkayba, Charafeddine Jama, Fouad Bentiss, Christophe Roos. 2-Amino-1-(4aminophenyl)-1H-pyrrolo(2,3-b)quinoxaline-3- carbonitrile as an efficient inhibitor for the corrosion of C38 steel in hydrochloric acid solution. International Journal of Electrochemical Science, 2020, 15, pp.2326-2334. 10.20964/2020.03.46 . hal-02927036

\section{HAL Id: hal-02927036 \\ https://hal.univ-lille.fr/hal-02927036}

Submitted on 1 Sep 2020

HAL is a multi-disciplinary open access archive for the deposit and dissemination of scientific research documents, whether they are published or not. The documents may come from teaching and research institutions in France or abroad, or from public or private research centers.
L'archive ouverte pluridisciplinaire HAL, est destinée au dépôt et à la diffusion de documents scientifiques de niveau recherche, publiés ou non, émanant des établissements d'enseignement et de recherche français ou étrangers, des laboratoires publics ou privés. 


\title{
2-Amino-1-(4-aminophenyl)-1H-pyrrolo(2,3-b)quinoxaline-3- carbonitrile as an efficient inhibitor for the corrosion of $\mathbf{C 3 8}$ steel in hydrochloric acid solution
}

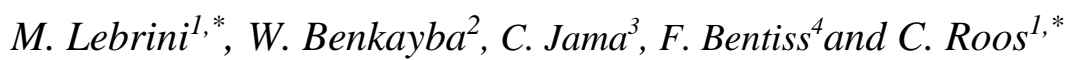 \\ ${ }^{1}$ Laboratoire Matériaux et Molécules en Milieux Agressif ; EA 7526, Département Scientifique \\ Interfacultaire, Campus Universitaire de Schoelcher B.P. 7209 F - 97275 Schoelcher, Martinique, \\ France \\ ${ }^{2}$ Laboratoire d'Électrochimie et Chimie Analytique (LECA), Faculté des Sciences - Agdal, Université \\ Mohammed V - Rabat, Morocco \\ ${ }^{3}$ Univ. Lille, CNRS, INRA, ENSCL, UMR 8207, - UMET - Unité Matériaux et Transformations, F- \\ 59000 Lille, France \\ ${ }^{4}$ Laboratory of Catalysis and Corrosion of Materials, Faculty of Sciences, Chouaib Doukkali \\ University, Po Box 20, M-24000 El Jadida, Morocco \\ *E-mail: $\underline{\text { mounim.lebrini@ univ-antilles.fr, christophe.roos@univ-antilles.fr }}$
}

Received: 17 June 2019 / Accepted: 25 November 2019 / Published: 10 February 2020

The inhibiting properties of 2-Amino-1-(4-aminophenyl)-1H-pyrrolo(2,3-b)quinoxaline-3-carbonitrile (AHPQC) were examined of C38 steel corrosion in molar hydrochloric acid using electrochemical techniques. Impedance data displayed the AHPQC inhibits C38 steel corrosion becoming the adsorbate at metal/electrolyte interfaces. Polarization study indicated that AHPQC is an anodic-cathodic inhibitor. The inhibition efficiencies of AHPQC calculated by both methods reaches $91 \%$. The Langmuir adsorption isotherm was observed for the AHPQC adsorption and its adsorption is realized by physical adsorption; due to the protonated forms of the AHPQC molecule in acid medium. XPS technique was used to discuss the mechanism for the adsorption process of the AHPQC molecule.

Keywords: AHPQC molecule; Molar hydrochloric acid; Inhibition; XPS; Electrochemical techniques.

\section{INTRODUCTION}

Organic compounds are extensively used to decrease the corrosion of metals and alloys in aqueous media such acidic solutions. Therefore, various studies regarding the inhibition of metal corrosion using organic compounds as corrosion inhibitors: triazole [1-3], oxathiadiazole [4-5] and carbanitriles derivatives [6-7]. These molecules usually consist of an aromatic, heteroaromatic having 
organic groups, non-binding electrons and heteroatoms. Quinoxaline molecules are a main class of heterocycle compounds, it's a benzoheterocycles containing an aromatic rings, benzene and pyrazine. Consequently, quinoxaline derivatives can be used as corrosion inhibitors.

Quinoxaline derivatives have been used in pharmacological industry [8-11] and biological activities [12-13]. Quinoxaline derivatives have found applications as corrosion inhibitors [14-16]. The activity demonstrated by the cited compounds was significantly reliant on the substituents of the quinoxaline ring, with the benzene-substituted derivatives showing the highest levels of protection activity.

The current study is a continuation of study on the effect of quinoxaline derivatives. The inhibiting effects of AHPQC molecules as an effective and efficient corrosion inhibitor for C38 steel in molar hydrochloric acid were discussed on the basis of the electrochemical and XPS technique. The select of the inhibitor is established on structure considerations; the AHPQC molecule has aromatic rings with delocalized $\pi$-electrons and nitrogen atoms in several forms: quinoxaline, pyrrole, nitrile, aniline and amine. These aspects favor the interaction of inhibitor molecule with surface metal.

\section{EXPERIMENTAL}

Corrosion experiments have been realized on C38 steel electrodes. The chemical structure of the tested inhibitors is shown in Figure 1. The investigated compound is a commercial product (Aldrich, P97\%). All the tests were performed using an electrochemical three-electrode cell as defined in an earlier study [17].

Impedance spectroscopy and polarization curves were used to determine the corrosion inhibition of the AHPQC using a VSP electrochemical measurement system (Bio-Logic). All the specifics parameters of the electrochemical methods were done in a past study [17].

The inhibition efficiency is calculated by the equation 1 with the polarization resistance $(R \mathrm{p})$ values.

$$
\operatorname{IE}(\%)=\left[\left(R_{p}-R_{p}{ }^{\circ}\right) / R_{p}\right] \times 100
$$

Where $\mathrm{R}_{\mathrm{p}}{ }^{0}$ and $\mathrm{R}_{\mathrm{p}}$ are the polarization resistance values in the absence and presence of AHPQC, respectively. The inhibitor efficiency $(I E)$ is also calculated from the electrochemical impedance spectroscopy data by the formula:

$$
\operatorname{IE}(\%)=\left[\left(R_{\mathrm{ct}}-R_{\mathrm{ct}}^{0}\right) / R_{\mathrm{ct}}\right] \times 100
$$

where $R_{\mathrm{ct}}{ }^{0}$ and $R_{\mathrm{ct}}$ are respectively the charge transfer resistance in the absence and presence of AHPQC.

$\mathrm{X}$-ray photoelectron spectroscopy spectra were detailed resulting the procedure described in the reference [17]. XPS investigates were experienced on pure AHPQC and on the treated steel surface. 


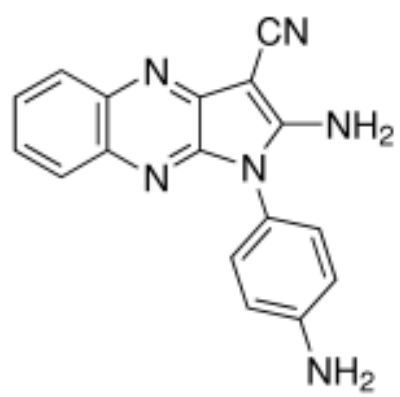

Figure 1. The chemical structure of 2-Amino-1-(4-aminophenyl)-1H-pyrrolo(2,3-b)quinoxaline-3carbonitrile.

\section{RESULTS AND DISCUSSION}

\subsection{Polarization study}

Polarisation results of the $\mathrm{C} 38$ steel in molar hydrochloric acid of AHPQC are exposed in Figure 2. It is observable from Figure 2 that, the adding of AHPQC to the corrosive solution moves the potential to positive values, while there was not a specific relation between $E_{\text {corr }}$ and inhibitor concentrations. As it can be also seen, the anodic and cathodic reactions are changed by the adding inhibitor. This modification indicates that, the addition of AHPQC to corrosive solution decreases the anodic dissolution of steel and also retards the cathodic hydrogen evolution reaction. The inhibiting effect of AHPQC can be correlated to its adsorption on the metal surface. It should also be noted that the desorption potential values are practically constant (around $-300 \mathrm{mV} / \mathrm{ECS}$ ) for the different concentrations studied. This suggests that the values of the desorption potential of the inhibitor are slightly affected by the inhibitor molecules. According to the fit of electrochemical parameters (Table 1), the C38 steel surface in molar hydrochloric acid had the parameter of $R_{p}=76 \mathrm{k} \Omega . \mathrm{cm}^{2}$ When covered with inhibitor, the $R_{p}$ increased for all of the studied concentrations. $I E(\%)$ calculated from equation 1 , increase also with inhibitor concentrations, attainment a $91 \%$ at $1.2 \mathrm{mM}$.

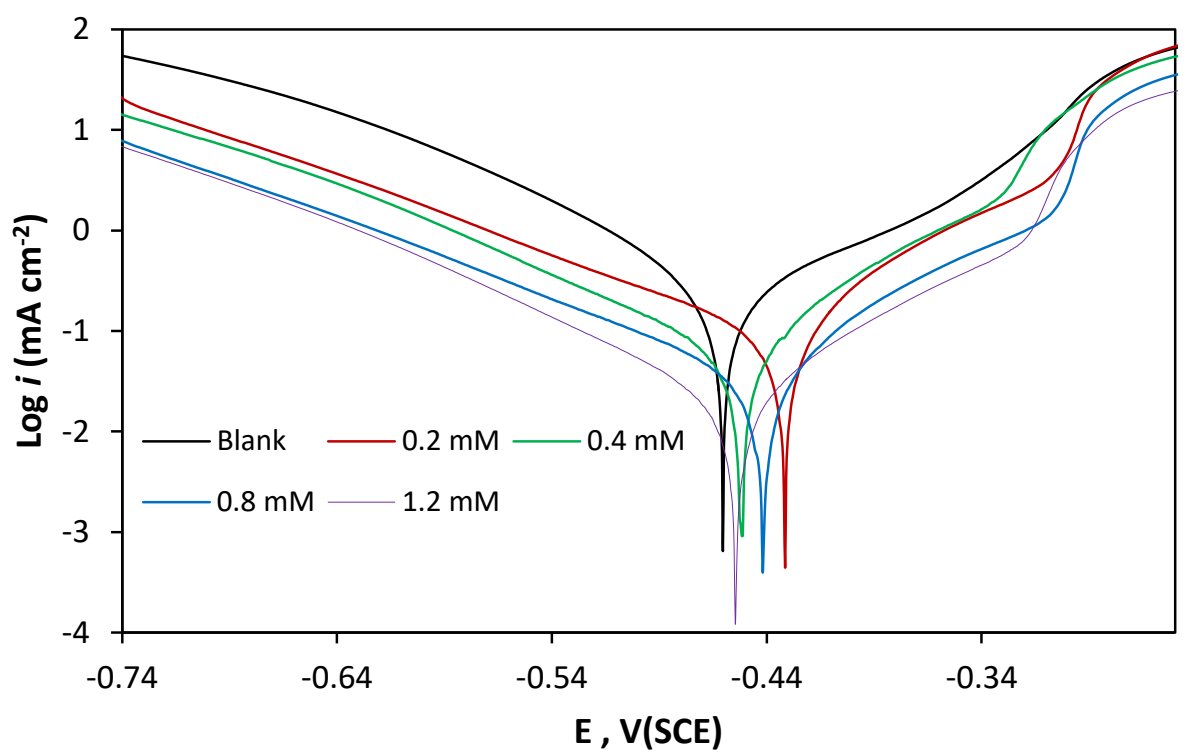

Figure 2. Polarization curves for C38 steel in hydrochloric acid containing AHPQC molecule. 
Table 1. Parameters Polarization curves for $\mathrm{C} 38$ steel in hydrochloric acid containing AHPQC molecule.

\begin{tabular}{|llll|}
\hline Concentrations & $\boldsymbol{E}_{\text {corr }}$ vs $\boldsymbol{S C E}$ & $\boldsymbol{R}_{\boldsymbol{p}}$ & $\boldsymbol{I E}$ \\
\hline $\mathbf{m M})$ & $(\mathrm{mV})$ & $\left(\Omega . \mathrm{cm}^{2}\right)$ & $(\%)$ \\
\hline $\mathbf{1 M ~ H C l}$ & -463 & 76 & \\
\hline $\mathbf{0 . 2}$ & -431 & 380 & 80 \\
\hline $\mathbf{0 . 4}$ & -450 & 447 & 83 \\
\hline $\mathbf{0 . 8}$ & -443 & 543 & 86 \\
\hline $\mathbf{1 . 2}$ & -455 & 844 & 91 \\
\hline
\end{tabular}

\subsection{Impedance study (EIS)}

The Impedance diagrams of C38 steel in hydrochloric acid containing AHPQC are exposed in Figure 3. All the obtained Nyquist plots give one semicircle proposing that inhibition of metallic corrosion proceeding in the present study is due to retardation of electron charge transfer process which is revealed by one-time constant in the Bode diagrams for the $0.8 \mathrm{mM} \mathrm{AHPQC}$ as an example (Figure 4). At high frequency, The $\log |Z|$ and phase angle values decline to zero representative of a typical resistive comportment of the mild steel, consequential to solution resistance happened between the saturated calomel and working electrodes [18]. The obtained impedance plots can be elucidated by contribution of an equivalent circuit containing the solution resistance $\left(R_{S}\right)$, the charge transfer resistance $\left(R_{c t}\right)$ and constant phase element (CPE) as described in the Figure 5.

The double layer capacitance was derived using following relation:

$$
C \mathrm{dl}=\left(A \cdot R_{\mathrm{ct}}^{1-n}\right)^{1 / n}
$$

where $A$ is the amplitude comparable to a capacitance and $n$ is the phase shift, which is a degree of surface roughness. For more precise fit, the constant phase element (CPE) was used in the present study rather than double layer capacitance. The CPE impedance can be denoted as follows:

$$
\mathrm{ZCPE}=A^{-1}(\mathrm{i} \omega)^{-n}
$$

Where $\omega$ is the angular frequency (in $\operatorname{rad~s}^{-1}$ ) and $i^{2}=-1$ is the imaginary number

All the electrochemical parameters and the inhibitor efficiency registered in Table 2. It was noted that the $R_{c t}$ values rise while the $C_{d l}$ values decline in the presence of inhibitor. This rise in $R_{c t}$ and decline in $C_{d l}$ values with AHPQC molecule, as related to that in its absence, can be propose that AHPQC molecule reacts by adsorption at the metal/solution interface. The values of $n$ are superior in the presence of AHPQC than in its absence, signifying that surface roughness is enhanced owing to formation of protective film on surface. The inhibition efficiency calculated from EIS presented the similar sequence with change in concentration as those exhibited by linear polarization measurements. 


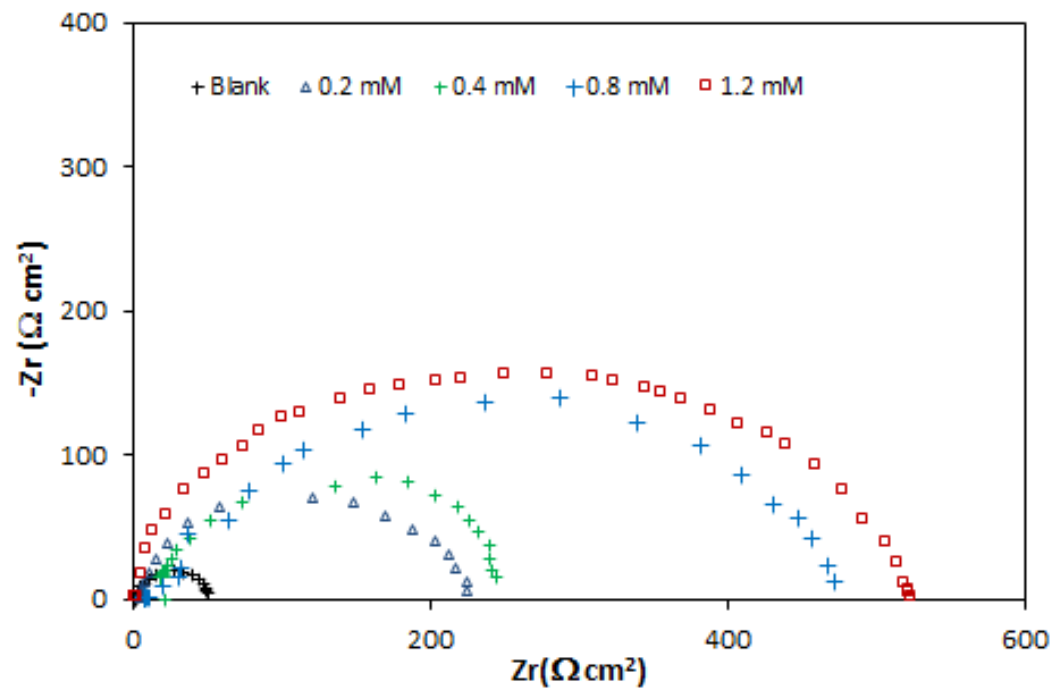

Figure 3. Nyquist diagrams for C38 steel in hydrochloric acid containing AHPQC molecule.

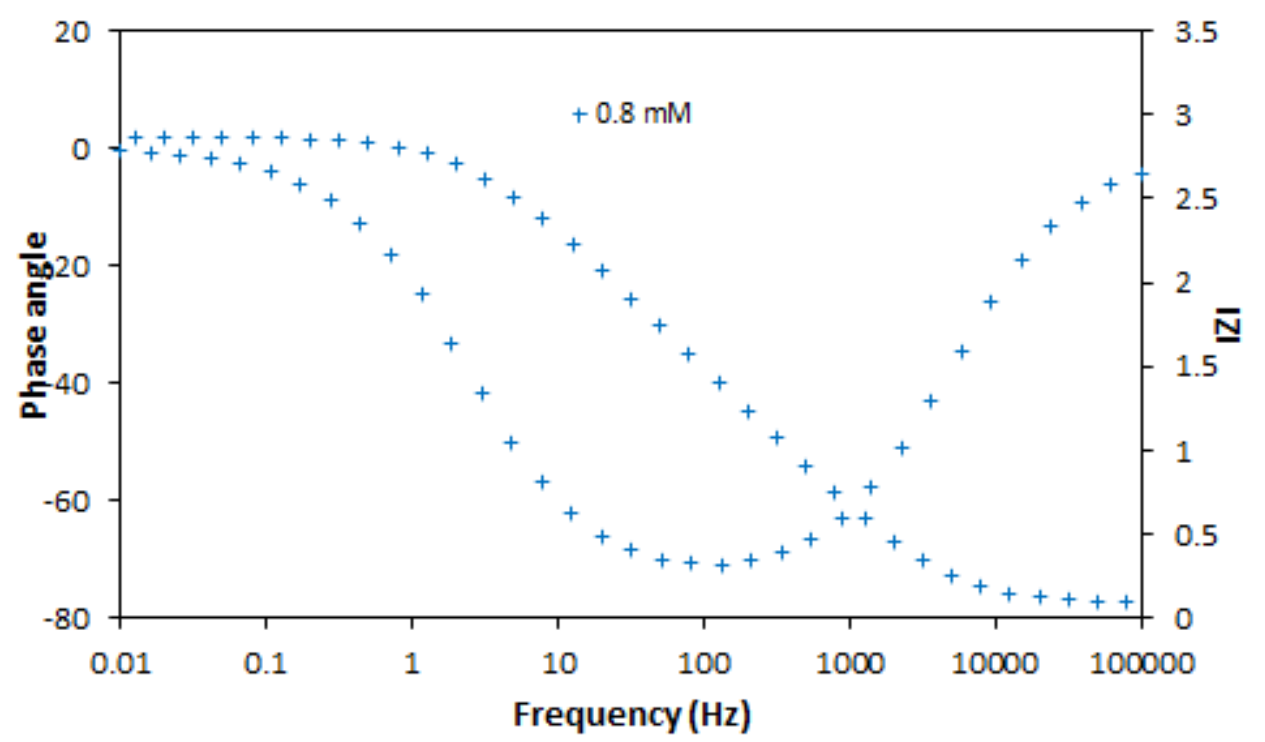

Figure 4. Bode diagrams for $\mathrm{C} 38$ steel in hydrochloric acid containing $0.8 \mathrm{mM}$ AHPQC.

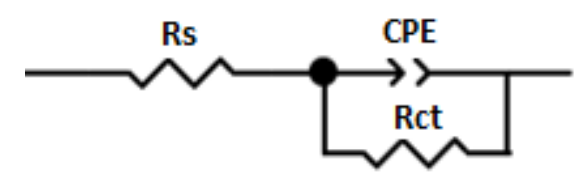

Figure 5. Equivalent circuit used for adjustment of the impedance diagrams. 
Table 2. The electrochemical parameters and the inhibitor efficiency for C38 steel in hydrochloric acid containing AHPQC molecule.

\begin{tabular}{|cccccc|}
\hline Inhibitor & $\boldsymbol{R}_{\mathrm{ct}}$ & $\boldsymbol{A} \mathbf{1 0}^{\mathbf{4}}$ & $\boldsymbol{n}$ & $\boldsymbol{C}_{\boldsymbol{d l}}$ & $\boldsymbol{I E}$ \\
& $\left(\Omega . \mathrm{cm}^{2}\right)$ & $\left(\Omega^{-1} \mathrm{~s}^{\mathrm{n}} \mathrm{cm}^{-2}\right)$ & & $\left(\mu \mathrm{F} . \mathrm{cm}^{-2}\right)$ & $(\%)$ \\
\hline $1 \mathrm{M} \mathrm{HCl}$ & $51 \pm 0.02$ & $9.50 \pm 0.05$ & $0.853 \pm 0.014$ & 563 & \\
\hline $0.2 \mathrm{mM}$ & $220 \pm 0.81$ & $3.91 \pm 0.01$ & $0.797 \pm 0.008$ & 209 & 77 \\
\hline $0.4 \mathrm{mM}$ & $252 \pm 2.01$ & $3.89 \pm 0.07$ & $0.762 \pm 0.014$ & 188 & 80 \\
\hline $0.8 \mathrm{mM}$ & $476 \pm 2.08$ & $1.24 \pm 0.02$ & $0.803 \pm 0.008$ & 62 & 89 \\
\hline $1.2 \mathrm{mM}$ & $520 \pm 2.73$ & $1.06 \pm 0.12$ & $0.824 \pm 0.015$ & 57 & 90 \\
\hline
\end{tabular}

\subsection{Adsorption behavior and XPS analyses}

Langmuir, Temkin, and Frumkin isotherms are verified to discover the inhibitor adsorption isotherm. The results obtained in the figure 6 displayed that Langmuir isotherm offers the finest fit. The Langmuir isotherms can be denoted as follows:

$$
C_{i n h} / \theta=1 / K+C_{i n h}
$$

The surface coverage values $(\theta)$ of various concentrations of the inhibitor are calculated by the equation 6 , where $I E$ is the inhibitor efficiency calculated from the electrochemical impedance spectroscopy and LP data.

$$
\theta=I E / 100
$$

The interception of the line $C_{\mathrm{inh}} / \theta$-axis gives the value of the equilibrium constant of the adsorption process $\left(K_{\text {ads }}\right)$. So the calculated value of $K_{\text {ads }}$ permits to calculate the standard free energy of adsorption $\left(\Delta G^{\circ}{ }_{a d s}\right)$ value from the equation 7.

$$
\Delta \mathrm{G}_{\text {ads }}^{\circ}=-\mathrm{RT} \ln \left(55.5 \mathrm{~K}_{\mathrm{ads}}\right)
$$

Where $R$ is the universal gas constant and $T$ is the absolute temperature. The calculated $\Delta G^{\circ}$ ads values are $-14.63 \mathrm{~kJ} . \mathrm{mol}^{-1}$ and $-14.24 \mathrm{~kJ} \mathrm{~mol}^{-1}$ from EIS and LP data, respectively. The found values are around $-20 \mathrm{~kJ} \mathrm{~mol}^{-1}$ suggest a physisorption mechanism of AHPQC molecule on surface C38 steel.

The XPS tests are realized for the AHPQC molecule and the treated steel following to $3 \mathrm{~h}$ of immersion in hydrochloric acid containing $1.2 \mathrm{mM}$ of AHPQC. All the groups binding energies and the equivalent assignment for each peak component for the obtained XPS spectra are given in Table 5.

The $\mathrm{C} 1 \mathrm{~s}$ XPS spectrum indicates three components. The one which positioned at $285.7 \mathrm{eV}$ can be assigned to $\mathrm{C}-\mathrm{C}, \mathrm{C}=\mathrm{C}$ and $\mathrm{C}-\mathrm{H}$ aromatic [19]. The second peak situated at $286.3 \mathrm{eV}$ attributed to $\mathrm{C}=\mathrm{N}$ and $\mathrm{C}-\mathrm{N}[20]$ and the last one $288.9 \mathrm{eV}$ attributed to the $\mathrm{C}=\mathrm{N}$ structure.

Three peaks at 399.9, 400 and $400.5 \mathrm{eV}$ were detected for the $\mathrm{N} 1 \mathrm{~s}$ spectrum for which to three components. The first one correspond to the unprotonated $\mathrm{N}$ atoms of aniline and amine. The second is attributed to the nitrogen in the nitrile group. The third component is also attributed to the nitrile group. 
After immersion in acid medium containing $1.2 \mathrm{mM}$ of AHPQC. The $\mathrm{C} 1 \mathrm{~s}, \mathrm{~N} 1 \mathrm{~s}$ XPS results shows practically similar characteristic bands of the pure AHPQC molecules (Table 5). It should be noted that a binding energies displacements were observed on the steel substrate treated with AHPQC. Demonstrating a probable chemical modification of the AHPQC molecules after adsorption. As example the presence of the $\mathrm{C}=\mathrm{N}^{+}$form in the monoprotonated or the diprotonated of the nitrogen atoms of quinoxaline, confirms the hypothesis of a possible chemical change of the AHPQC molecules. The XPS confirms a chemisorption of AHPQC molecules not including a physical adsorption.

The deconvolution of the high peak resolution of $\mathrm{Fe} 2 \mathrm{p}_{3 / 2}$ spectrum display three peaks (Table 5). The first one at $711.6 \mathrm{eV}$ correspond to $\mathrm{Fe}^{3+}$ is ascribed to ferric compounds like $\mathrm{Fe}_{2} \mathrm{O}_{3}$ and/or $\mathrm{FeOOH}$. The peak positioned at $712.5 \mathrm{eV}$ is attributed to the presence of a small concentration of $\mathrm{FeCl}_{3}$ on the surface. The last one positioned at $714 \mathrm{eV}$ indicates the presence of $\mathrm{Fe}$ (III) [21]. The results obtained by XPS analysis supporting the adsorption of inhibitors on the steel surface.

The adsorption mechanism can also be discussed in relation to the AHPQC structure. The AHPQC structure has nitrogen atoms in several forms: quinoxaline, pyrrole, nitrile, aniline and amine. In acid solution, The AHPQC molecule can be protonized, principally on the nitrogen atoms. In $\mathrm{HCl}$, the aniline exists in the anilinium ion form (Figure 7e). When aniline is protonated, the resonance stabilization is no longer present, for the reason that the unshared pair is neutralized by a proton $\mathrm{H}+$ and its incorporation in the benzene ring is impossible. Consequently, the anilinium ion gives only one protoned form. And the protonation of the primary amines group produces ammonium ions (Figure 7c) and the protonation of nitrile gives nitrilium ion (Figure 7a). In addition, the protonated form of the pyrrole heterocycle gives iminium ions, and contributes to the delocation of $\pi$ electrons with the adjacent quinoxaline ring. This delocation offers a number of mesomeric forms. The quinoxaline can give two forms the monoprotonated and the diprotonated. Therefore, the diprotonated takes place significantly only in a strongly acidic medium (in our case the $\mathrm{pH}$ is around 0 ). The monoprotonated one of the two nitrogen atoms (Figure 7b). The diprotonated of the two nitrogen atoms of quinoxaline (figure 7d) gives a large contribution of the resonance form, characterized by the delocalization of the positive charge in the benzene ring, giving a number of mesomeric forms [22].

As cited before, the adsorption mechanism of the AHPQC includes a physisorption. It means that, the AHPQC is able to electrostatically adsorb on the steel surface covered with principal adsorbed $\mathrm{Cl}$ - ions. In the usual condition (acidic medium), all the nitrogen atoms exists in the protonated forms as mentioned before (Figure7). Consequently, it may be supposed that, the first contact between the metal surface and the AHPQC is concerning metal and the protonated form. Thus, the protonated form can adsorb directly on the chloride-covered electrode surface through a simple electrostatic attraction between the cation forms of the molecule and chloride ions [23]. The adsorption of the AHPQC take place also through donor-acceptor interactions concerning the $\pi$ electrons and the vacant " $\mathrm{d}$ " orbitals of iron surface atoms [24]. 


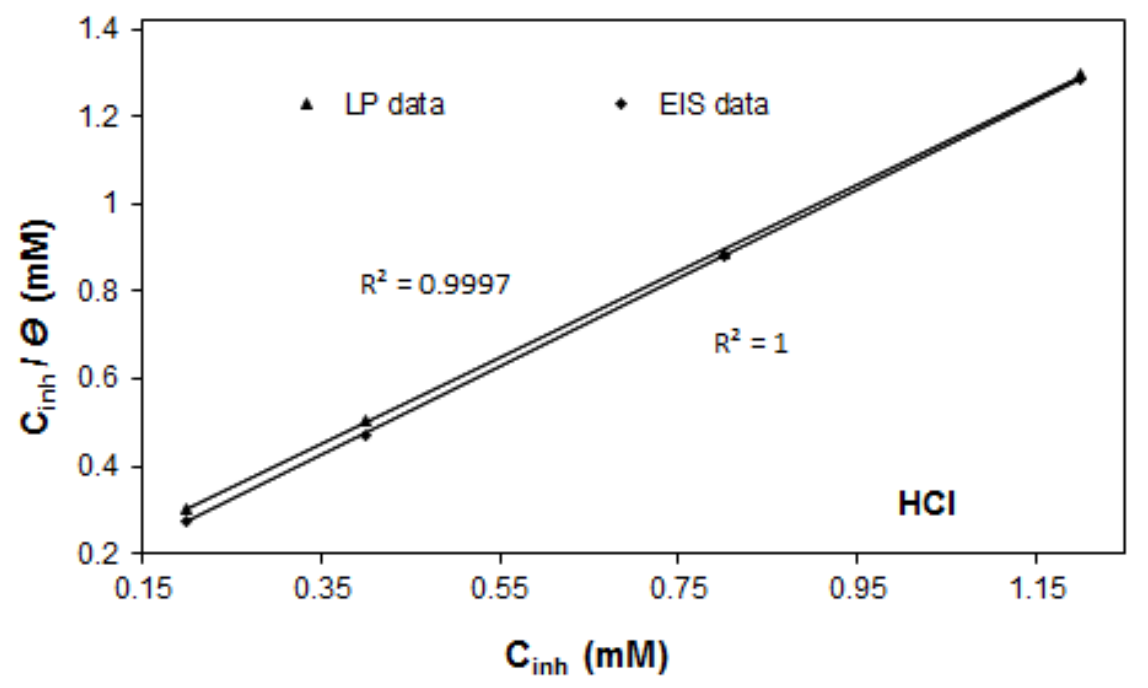

Figure 6. Langmuir isotherm for $\mathrm{C} 38$ steel in $1 \mathrm{M} \mathrm{HCl}$ containing different concentrations of AHPQC.<smiles></smiles><smiles>Nc1ccccc1</smiles>

Figure 7. The protonated forms of the nitrogen atom of the AHPQC molecule in acid medium.

Table 3. the groups binding energies and the equivalent assignment for AHPQC molecule and steel treated with AHPQC in acid medium at $25^{\circ} \mathrm{C}$.

\begin{tabular}{|c|c|c|c|c|c|c|}
\hline Substrate & $\mathrm{C} 1 \mathrm{~s}$ & & $\mathrm{~N}$ 1s & & $\mathrm{Fe} 2 \mathrm{p} \mathrm{3/2}$ & \\
\hline & $\mathrm{BE}(\mathrm{eV})$ & Assignment & $\mathrm{BE}(\mathrm{eV})$ & Assignment & $\mathrm{BE}(\mathrm{eV})$ & Assignment \\
\hline \multirow{3}{*}{ AHPQC } & 285.7 & $\begin{array}{l}\mathrm{C}-\mathrm{C} / \mathrm{C}=\mathrm{C} / \\
\mathrm{C}-\mathrm{H} \text { aromatic }\end{array}$ & 399.9 & $=\mathrm{N}-/ \mathrm{C}-\mathrm{N}$ & - & - \\
\hline & 286.3 & $\mathrm{C}=\mathrm{N} / \mathrm{C}-\mathrm{N}$ & 400 & $\mathrm{C}-\mathrm{N} /-\mathrm{CN}$ & - & - \\
\hline & 288.9 & $\mathrm{C}=\mathrm{N}$ & 400.5 & $-\mathrm{CN}$ & - & - \\
\hline \multirow{3}{*}{$\begin{array}{l}\text { AHPQC } \\
\text { treated steel } \\
\text { substrate }\end{array}$} & 285.7 & $\begin{array}{l}\mathrm{C}-\mathrm{C} / \mathrm{C}=\mathrm{C} / \\
\mathrm{C}-\mathrm{H} \text { aromatic }\end{array}$ & 399.9 & $=\mathrm{N}-/ \mathrm{C}-\mathrm{N}$ & 711.6 & $\mathrm{Fe}^{3+}$ \\
\hline & 286.5 & $\mathrm{C}=\mathrm{N} / \mathrm{C}-\mathrm{N}$ & 400 & $\mathrm{C}-\mathrm{N} /-\mathrm{CN}$ & 712.5 & $\mathrm{FeCl}_{3}$ \\
\hline & 289.1 & $\mathrm{C}=\mathrm{N}^{+}$ & 400.5 & $-\mathrm{CN}$ & 714 & $\mathrm{Fe}(\mathrm{III})$ \\
\hline
\end{tabular}




\section{CONCLUSIONS}

The present study illustrates the subsequent results:

1- The AHPQC molecule is an effective corrosion inhibitors for C38 steel in molar hydrochloric acid using electrochemical techniques and its efficiencies reaches $91 \%$.

2- The polarization method revealed that AHPQC inhibit anodic and cathodic reactions.

3- The AHPQC adsorption on the C38 steel in molar hydrochloric acid solution obeys to Langmuir adsorption isotherm with high correlation coefficient.

4- The AHPQC inhibition is defined by a physical adsorption; due to the protonated forms of the AHPQC molecule in acid medium.

5- The XPS confirms a chemisorption of AHPQC molecules onto the steel surface.

\section{References}

1. C.M. Fernandes, L. X. Alvarez, N.E. dos Santos, A. C. Maldonado Barrios, E.A. Ponzio, Corros. Sci., 149 (2019) 185.

2. N. Shet, R. Nazareth, P.A. Suchetan, Chemical Data Collec., 20 (2019) Article 100209.

3. Y. El Bakri, L. Guo, El H. Anouar, El M. Essassi, J. Mol. Liq, 274 (2019) 759.

4. P. Rugmini Ammal, M. Prajila, Abraham Joseph, J. Environ. Chem. Eng. 6 (2018) 1072.

5. T. A. Salman, K. F. Al-Azawi, I.M. Mohammed, S. B. Al-Baghdadi, A.A. H. Kadhum, Results in Physics, 10 (2018) 291.

6. C. Verma, M. A. Quraishi, H. Lgaz, L. O. Olasunkanmi, E. Ebenso J. Mol. Liq, 283 (2019) 491.

7. A. Singh, K. R. Ansari, M. A. Quraishi, H. Lgaz, Y. Lin, J. Alloys Compd., 762 (2018) 347.

8. A. Carta, G. P., M. Nikookar, P. Sanna, L. Sechi, S. Zanetti, Eur. J. Med. Chem., 37 (2002) 355.

9. A.J. Belén Zarranz, I. Aldana, A. Monge, Bioorg. Med. Chem., 12 (2004) 10.

10. A.P. Carlos Barea, D. Castillo, M. Zimic, M. Quiloano, S. Galiano, S. P. Silanes, A. Monge, A.E. Deharo, I. Aldana, Bioorg. Med. Chem. Lett., 21 (2011) 4.

11. N. Kulkarni, V.K. R, B.N. Kirasur, Mallinath H. Hugar, Med. Chem. Res., 21 (2012) 8.

12. S.A. Khan, J.K. Saleem, Z. Khan, Eur. J. Med. Chem., 42 (1) (2007) 103.

13. A. Patidar, J. M., A. Mobiya, G. Selvam, Int. J. PharmTech Res., 3 (2011) 386.

14. Z. El Adnani, M. M, M. Sfaira, M. Benzakour, A. Benjelloun, M. Ebn Touhami, B. Hammouti, A.M. Taleb, Int. J. Electrochem. Sci., 7 (2012) 13.

15. I.B. Obot, N.O. Obi-Egbedi, Corros. Sci., 52 (1) (2010) 3.

16. Mwadham M. Kabanda, Int. J. Electrochem. Sci., 7 (2012) 20.

17. M. Chevalier, F. Robert, M. Traisnel, C. Roos, M. Lebrini, Electrochim. Acta 131 (2014) 96.

18. C.B. Verma, M.A. Quraishi, E.E. Ebenso, Int. J. Electrochem. Sci. 8 (2013) 12894.

19. M. Finsgar, Corros. Sci. 72 (2013) 90.

20. M. Finsgar, S. Fassbender, S. Hirth, I. Milosev, Mater. Chem. Phys. 116 (2009) 198.

21. M. Tourabi, K. Nohair, M. Traisnel, C. Jama, F. Bentiss, Corros. Sci. 75 (2013) 123.

22. T. Caronna, G. P. Gardini, F. Minisci, J. Heterocyclic Chem., 13 (1976) 955.

23. M. Scendo, D. Poddebniak, J. Malyszko, J. Appl. Electrochem. 33 (2003) 287.

24. N. Hackerman, A.C. Makrids, J. Phys. Chem. 59 (1955) 707.

(C) 2020 The Authors. Published by ESG (www.electrochemsci.org). This article is an open access article distributed under the terms and conditions of the Creative Commons Attribution license (http://creativecommons.org/licenses/by/4.0/). 